\title{
DICER1 Gene Mutation
}

National Cancer Institute

\section{Source}

National Cancer Institute. DICER1 Gene Mutation. NCI Thesaurus. Code C137691.

A change in the nucleotide sequence of the DICER1 gene. 